\title{
Potassium and Nitrogen Fertigation Frequency on Pineapple Yield and Fruit Quality
}

\author{
Ana Maria Alves de Souza Ribeiro ${ }^{1}$, Robson Bonomo ${ }^{2}$, Moises Zucoloto ${ }^{3}$, Fábio Oseias dos Reis da Silva ${ }^{4}$, \\ Mariana Vasconcelos Barroca ${ }^{5}$, Alan de Lima Nascimento ${ }^{2}$, Augusto Moreira de Paula Magalhães ${ }^{2}$, \\ Alex Campanharo ${ }^{2}$, Gleison Oliosi ${ }^{2} \&$ Lucas Dalmolin Ciarnoschi $^{6}$ \\ ${ }^{1}$ Postgraduate Program in Tropical Agriculture, Federal University of Espírito Santo, São Mateus, ES, Brazil \\ ${ }^{2}$ Departament of Agrarian and Biological Sciences, Federal University of Espírito Santo, São Mateus, ES, Brazil \\ ${ }^{3}$ Departamento de Produção Vegetal, Federal University of Espírito Santo, Alegre, ES, Brazil \\ ${ }^{4}$ Federal University of Lavras, Lavras, MG, Brazil \\ ${ }^{5}$ Programa de Pós-graduação em Ciência do Solo, Federal University of Paraná, Curitiba, PR, Brazil \\ ${ }^{6}$ Programa de Pós-graduação em Engenharia Florestal, Federal University of Paraná, Curitiba, PR, Brazil \\ Correspondence: Ana Maria Alves de Souza Ribeiro, Federal University of Espírito Santo, São Mateus, ES, \\ Brazil. E-mail: anamaria.acre@gmail.com
}

Received: December 4, 2018 Accepted: March 23, $2019 \quad$ Online Published: May 15, 2019

doi:10.5539/jas.v11n6p416 URL: https://doi.org/10.5539/jas.v11n6p416

The research is financed by Coordenação de Aperfeiçoamento de Pessoal de Nivel Superior (CAPES).

\begin{abstract}
Pineapple is a nutritionally demanding crop, with emphasis on potassium and nitrogen nutrients. In this context, the aim of this paper was to study the effect of nitrogen $(\mathrm{N})$ and potassium $(\mathrm{K})$ fertigation frequencies on the physical-chemical fruit characteristics of 'Pérola' pineapple crop. The experiment was conducted in a randomized block design, with 18 treatments and 4 replications. It was used a factorial scheme $(4 \times 4)+1+1$, which represents: four $\mathrm{N}$ fertigation frequencies applied by surface drip irrigation $(4,7,27$ and 54 times throughout the crop cycle); four $\mathrm{K}$ fertigation frequencies (4, 9, 35 and 70 times); one additional treatment (irrigated, but without fertigation); and one control (non irrigated and non fertigated). The fruit characteristics analyzed were: fruit mass with crown, yield, soluble solids, $\mathrm{pH}$, titratable acidity and SS/TA ratio. The $\mathrm{N}$ fertigation frequencies had no effect on variables evaluated, however, the $\mathrm{K}$ frequencies had a significant influence on fruit mass with crown, yield and $\mathrm{pH}$. The results showed that the effect of $\mathrm{K}$ frequencies applied through fertigation on pineapple yield and fruit physical-chemical quality was more pronounced in comparison to the effect of $\mathrm{N}$ applications. Monthly potassium fertigations, followed by four applications throughout the crop cycle, provided the greatest increase in fruit quality, allowing higher values of fruit mass, yield and $\mathrm{pH}$.
\end{abstract}

Keywords: Ananas comosus, fertilization, fruit quaility

\section{Introduction}

Pineapple is the third most cultivated tropical fruit in the world, with Brazil being the 14th largest producer (FAO, 2016). In 2017, Brazilian production was 1,704,403 tons in an area of 70,259 hectares with an average yield of $24 \mathrm{t} \mathrm{ha}^{-1}$. In the state of Espírito Santo, the area harvested was 2,415 hectares, producing 45,571 million fruits with an avegrage yield of 18,870 fruits $\mathrm{ha}^{-1}$ (IBGE, 2017).

Among the factors that affect production, fertilization has a direct influence on pineapple productivity and fruit quality (Mendes et al., 2011). Given the economic importance of pineapple crop to Brazil and to the state of Espírito Santo, there is a need for the use of new technologies such as irrigation and fertigation that provide efficiency gains in the use of fertilizers and optimize production. According to Papadopoulos (2001), the use of fertigation can be an alternative because it is directly related to the increase in productivity, improvement in fruit quality, efficient use of fertilizers during applications, energy and labor saving, and consequently higher economic return. 
The use of fertigation adds many benefits to farmers, since it combines two essential factors for plant growth and development: water and nutrients. Applying fertilizers in smaller parcels and higher frequency allows a dynamic supply of nutrients on soil according to crop stage requirement, which leads to an increase in the efficiency of the use of nutrients by plants and, consequently, greater productivity. Other advantages include: greater use of irrigation equipment, less soil compaction, reduction of physical damage on plants with reduced traffic of machines within the area, reduction of environment contamination due to the best use of the mobile nutrients in the soil when applied by drip irrigation and decrease in the use of labor. This technique, when used rationally, can promote higher plant development and fruit quality, providing an increase in fruit grower competitiveness on the market (Simon et al., 2004).

The subdivision of $\mathrm{K}$ and $\mathrm{N}$ application has many advantages. For $\mathrm{K}$, it is due to the mobility of the nutrient in the soil, especially in sandy soils. In this case, smaller quantities should be applied to reduce leach losses. Furthermore, due to the high solubility of $\mathrm{K}$ fertilizer, it application through irrigation system becomes feasible. $\mathrm{K}$ is the nutrient most required and extracted by pineapple plants, its concentration occurs mainly in the fruits but also in the leaves (Souza, 1999). The $\mathrm{K}$ is presented on plants as $\mathrm{K}^{+}$cation, playing an important role in regulating the osmotic potential of cells and in the activation of enzymes involved in respiration and photosynthesis (Taiz \& Zeiger, 2013). Subdivision of N fertilization is recommended because of its high mobility in the soil, which is accentuated in sandy soil conditions and crops with low initial requirement of $\mathrm{N}$, being the nutrient most supplied via irrigation water (Borges \& Silva, 2011).

According to Teixeira et al. (2002) the influence of those elements reflects on productivity and fruit quality. The potassium increases the content of soluble solids and acidity, changes the color, increases fruit mass and diameter, produces higher firmness of the skin and pulp and reduces the browning of fruits. While $\mathrm{N}$ has a directly influence on fruit yield, size and mass, though it tends to reduce soluble solids and acidity. In this context, the aim of this paper was to study the effect of nitrogen $(\mathrm{N})$ and potassium $(\mathrm{K})$ fertigation frequencies on the yield and fruit quality of 'Pérola' pineapple crop.

\section{Materials and Methods}

\subsection{Local Description}

The experiment was carried out on the Experimental Farm of the Centro Universitário Norte do Espírito Santo (CEUNES), on the Federal University of Espírito Santo (UFES), located in São Mateus, northern region of the state, $18^{\circ} 40^{\prime} 32^{\prime \prime} \mathrm{S}$ and $39^{\circ} 51^{\prime} 39^{\prime \prime} \mathrm{W}$, Brazil. The city has an altitude of $37.7 \mathrm{~m}$, and has a dry and subhumid climate, characterized as Aw according to Köppen classification.

Observed data for the meteorological conditions of monthly average rainfall, crop evapotranspiration and global radiation during the period of the experiment is presented in Figure 1.

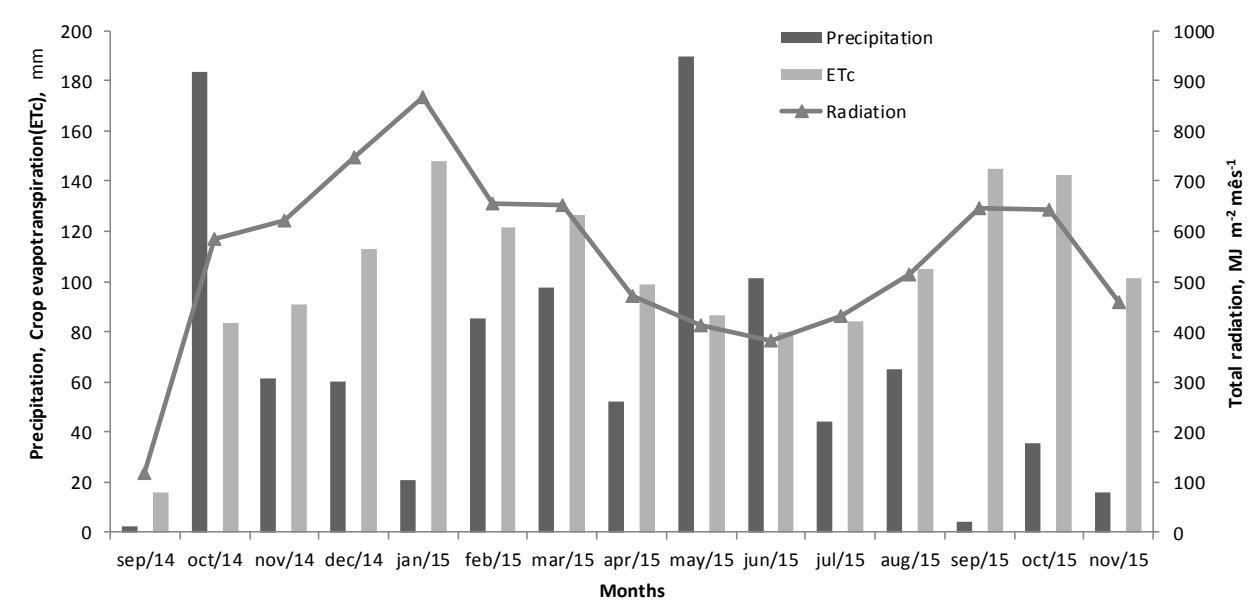

Figure 1. Annual rainfall precipitation ( $\mathrm{mm}$ ), crop evapotranspiration (ETc, $\mathrm{mm}$ ) and global solar radiation (MJ $\mathrm{m}^{-2}$ mês $^{-1}$ ) registered during pineapple crop cultivation on 2014/2015, São Mateus, ES

Source: INMET, (2015). 
The soil was classified as Utisol with sandy-loam texture. In previous sampling, the following average values were obtained for the soil chemical attributes: organic matter $=1.5$ dag kg ${ }^{-1} ; \mathrm{pH}\left(\mathrm{CaCl}_{2} 0.01 \mathrm{~mol} \mathrm{~L}^{-1}\right)=4.8 ; \mathrm{P}=$ $8.5 \mathrm{mg} \mathrm{dm}{ }^{-3} ; \mathrm{K}=34 \mathrm{mg} \mathrm{dm}{ }^{-3} ; \mathrm{Ca}=0.9 \mathrm{cmol}_{\mathrm{c}} \mathrm{dm}^{-3} ; \mathrm{Mg}=0.4 \mathrm{cmol}_{\mathrm{c}} \mathrm{dm}^{-3} ; \mathrm{H}+\mathrm{Al}=1.5 \mathrm{cmol}_{\mathrm{c}} \mathrm{dm}^{-3}$ and base saturation $=47.1 \%$.

\subsection{Characteristics of Treatments}

The experiment was conducted in a randomized block design, with 18 treatments and 4 replications. It was used a factorial scheme $(4 \times 4)+1+1$, which represents: four $\mathrm{N}$ fertigation frequencies applied on surface drip irrigation (4, 7, 27 and 54 times throughout the crop cycle); and four $\mathrm{K}$ fertigation frequencies $(4,9,35$ and 70 times throughout the crop cycle).

The treatments with subdivision of Nitrogen $(\mathrm{N})$ and Potassium $(\mathrm{K})$ applications by fertigation, were planned as following: T1: non-irrigated and non-fertigated treatment, with four manual applications of nitrogen and potassium on the soil surface throughout the crop cycle, designated as control; T2: irrigated and fertigated treatment, with fertigations in four applications for $\mathrm{N}$ and two weekly applications of $\mathrm{K}$; T3: treatment irrigated, with fertigations subdivided in four applications for $\mathrm{N}$ and weekly applications for $\mathrm{K}$; T4: irrigated and fertigated with four applications of $\mathrm{N}$ and monthly $\mathrm{K}$ applications; T5: irrigated and fertigated with four applications of $\mathrm{N}$ and K; T6: irrigated and fertigated with monthly $\mathrm{N}$ applications and twice a week for K; T7: irrigated and fertigated with monthly $\mathrm{N}$ applications and once a week for $\mathrm{K}$; T8: fertigated with monthly applications of $\mathrm{N}$ and potassium K; T9: fertigated with monthly applications of $\mathrm{N}$ and four applications of $\mathrm{K}$; T10: fertigated with weekly applications of $\mathrm{N}$ and twice a week for potassium K; T11: fertigated with weekly applications of $\mathrm{N}$ and $\mathrm{K}$; T12: fertigated with weekly applications of $\mathrm{N}$ and monthly for K; T13: fertigated with weekly applications of $\mathrm{N}$ and four applications of K; T14: fertigated with twice a week applications of N and K; T15: fertigated with twice a week applications of nitrogen $\mathrm{N}$ and once a week for potassium $\mathrm{K}$; T16: fertigated with twice a week applications of $\mathrm{N}$ and monthly for K; T17: fertigated with twice a week applications of $\mathrm{N}$ and four applications of $\mathrm{K}$; and an additional treatment, T18: irrigated and non-fertigated treatment, with four manual applications of $\mathrm{N}$ and $\mathrm{K}$ on the soil surface. The amount of NPK fertilizers applied and distributed throughout the growing cycle were determined following the recommendation of Benfica et al. (2011), with $310 \mathrm{~kg} \mathrm{ha}^{-1}$ of N (urea) and $480 \mathrm{~kg}$ $\mathrm{ha}^{-1}$ of $\mathrm{K}_{2} \mathrm{O}$ (potassium chloride) being used in all treatments. Phosphorus, as a single superphosphate $\left(18 \% \mathrm{P}_{2} \mathrm{O}_{5}\right)$ fertilizer, was applied at one time in the bottom of furrows at planting time, with $137 \mathrm{~kg} \mathrm{ha}^{-1}$ of $\mathrm{P}_{2} \mathrm{O}_{5}$. Micronutrients were supplied by two sprays of foliar fertilizer at a dosage of $1.5 \mathrm{~L} \mathrm{ha}^{-1}$. Fertilizer applications started in September. Nitrogen fertilizers were distributed until the seventh month after planting. For K, fertilizations were applied approximately until nine months after pineapple planting.

\subsection{Experiment Installation and Conducting}

The experimental plots were composed of double rows, $4.0 \mathrm{~m}$ long and $5.20 \mathrm{~m}$ wide. Each plot consisted of four double lines, with 80 plants per plot, spaced $0.40 \mathrm{~m}$ between plants, $0.30 \mathrm{~m}$ between single lines and $1.0 \mathrm{~m}$ between double lines, totaling a density of 38,462 plants per hectare.

The experiment was installed in September, using pineapple seedlings made from slips. At nine months after planting, the plants were submitted to flowering induction using Ethephon based product (2-chloro ethyl phosphonic acid), applied into the heart of pineapple plant $(50 \mathrm{ml} / \mathrm{plant})$. The formulation applied was $1.0 \mathrm{ml}$ of the commercial product, $20 \mathrm{~g}$ of urea and ice per liter of water. Before applications, the solution $\mathrm{pH}$ was checked and adjusted with 0.30 to $0.35 \mathrm{~g}$ of $\mathrm{Ca}(\mathrm{OH})_{2}$.

The irrigation system used was Surface drip irrigation, using dripperlines spaced $0.21 \mathrm{~m}$ between drippers and $1.30 \mathrm{~m}$ between lines, with a flow rate of $1.4 \mathrm{~L} \mathrm{~h}^{-1}$ per dripper and operating at $100 \mathrm{kPa}$. Fertiligation applications were done by means of a flow bypass tank type injector, one for each treatment.

The harvest was carried out at 14 months after planting, harvesting the twenty central fruits per plot.

\subsubsection{Variables Evaluated}

The yield was determined by weighing the fruits with crown (average mass of the fruits) multiplying by the planting density $(38,462$ plants per hectare). For the physical and chemical analyzes of fruit pulp, five fruits were selected in the laboratory, out of the twenty fruits per plot harvested in the field. The five fruits were selected according to the market standard quality, without damage and injuries by pests and diseases. The average mass of the fruits with crown was determined by weighing each single fruit in a semi-analytical balance. Soluble solids content $\left({ }^{\circ} \mathrm{Brix}\right)$ was estimated using a manual refractometer in samples taken from the median part of the fruits. From the fruits juice, extracted by centrifuge, determinations of titratable acidity (\% citric acid) and $\mathrm{pH}$ were performed. Then, the ratio between soluble solids and titratable acidity (SS/TA ratio) was calculated. 


\subsubsection{Statistical Analysis}

The data were subjected to Analysis of Variance (ANOVA). In case of significant values, the means of the treatments were compared by the Tukey test at 5\% probability, using the SISVAR program. For the control and additional treatments, linear contrasts were analyzed to verify the general effect of the fertigation.

\section{Results and Discussion}

There was no significant interaction, according to the analysis of variance, between the two main factors, the $\mathrm{N}$ and $\mathrm{K}$ fertigation frequencies, as well as the additional treatments, at $5 \%$ probability level by the $\mathrm{F}$ test, for all evaluated characteristics. The results indicate that the factors are independent, that is, the behavior of one factor does not depend on the levels of the other. In this case, the factors were studied separately.

For the average fruit mass with crown $(\mathrm{kg})$ and yield $\left(\mathrm{kg} \mathrm{ha}^{-1}\right)$, significant differences were observed in the subdivisions of $\mathrm{K}$ fertilization. However, this effect was not observed on $\mathrm{N}$ fertilizations, according to the results presented on Table 1.

In the comparison between the general effects of irrigation through linear contrast, there was no significant difference between the control and the irrigated treatment for all fruit characteristics evaluated at $5 \%$ probability by the $\mathrm{F}$ test (Tables 2 and 4). This indicates the possibility of using both the rainfed and irrigated production systems. Failure to obtain significant differences between irrigated (additional) and non-irrigated (control) treatment is possibly related to the fact that the pineapple plants have supplied its water requirements by rainfall during cultivation, since the accumulated precipitation during crop cycle was $1019.6 \mathrm{~mm}$ (Figure 1) and the crop requires from 1000 to $1500 \mathrm{~mm}_{\text {year }}{ }^{-1}$ of well distributed rainfall (Silva, 2014). Thus, the water supplied by the rain during the period studied was enough to allow adequate growth and development of plants.

Pineapple has a permanent demand for water relatively low, although it is essential for more uniform production. The requirement is variable throughout the cycle and depends on its stage of development. In tropical regions irrigation has been used to meet water demand in the months with lower rainfall rates (Melo et al., 2006).

Table 1. Average fruit mass with crown $(\mathrm{Kg})$ and yield $\left(\mathrm{kg} \mathrm{ha}^{-1}\right)$ of 'Pérola' pineapple fruits, due to nitrogen $(\mathrm{N})$ and potassium $(\mathrm{K})$ fertigation frequencies

\begin{tabular}{lll}
\hline \multirow{2}{*}{ Treatments } & \multicolumn{2}{c}{ Variables } \\
\cline { 2 - 3 } & Fruit Mass $(\mathrm{kg})$ & \multicolumn{1}{c}{ Yield $\left(\mathrm{kg} \mathrm{ha}^{-1}\right)$} \\
\hline Nfertigation frequencies & $1.472 \mathrm{a}$ & $56650.16 \mathrm{a}$ \\
$2 . \mathrm{N}=54$ & $1.505 \mathrm{a}$ & $57888.22 \mathrm{a}$ \\
$3 . \mathrm{N}=7$ & $1.416 \mathrm{a}$ & $54495.19 \mathrm{a}$ \\
$4 . \mathrm{N}=4$ & $1.459 \mathrm{a}$ & $56121.88 \mathrm{a}$ \\
Average & 1.463 & 56253.72 \\
$\mathrm{CV}(\%)$ & 6.22 & 6.22 \\
\hline$K$ fertigation frequencies & & \\
$1 . \mathrm{K}=70$ & $1.467 \mathrm{ab}$ & $56443.99 \mathrm{ab}$ \\
$2 . \mathrm{K}=35$ & $1.388 \mathrm{~b}$ & $53381.41 \mathrm{~b}$ \\
$3 . \mathrm{K}=9$ & $1.504 \mathrm{a}$ & $57851.68 \mathrm{a}$ \\
$4 . \mathrm{K}=4$ & $1.494 \mathrm{a}$ & $57478.37 \mathrm{a}$ \\
Average & 1.463 & 56253.72 \\
$\mathrm{CV}(\%)$ & 6.22 & 6.22 \\
\hline
\end{tabular}

Note. Means followed by the same letter do not differ statistically from each other, at the $5 \%$ probability level, by the Tukey test.

$\mathrm{N}=54$ applications (twice a week fertigations); $\mathrm{N}=27$ applications (once a week fertigations); $\mathrm{N}=7$ applications (monthly fertigations); $\mathrm{N}=4$ applications (fertigation divided in four applications) throughout crop cycle. $\mathrm{K}=70$ applications (twice a week fertigations); $\mathrm{K}=35$ applications (once a week fertigations); $\mathrm{K}=9$ applications (monthly fertigations); $\mathrm{K}=4$ applications (fertigation divided in four applications) throughout crop cycle. 
Table 2. Effect of irrigation on average fruit mass with crown $(\mathrm{Kg})$ and yield $\left(\mathrm{kg} \mathrm{ha}^{-1}\right)$ of pineapple 'Pérola' fruit with different frequencies of nitrogen $(\mathrm{N})$ and potassium $(\mathrm{K})$ application by fertigation

\begin{tabular}{lll}
\hline \multirow{2}{*}{ Treatments } & \multicolumn{2}{c}{ Variables } \\
\cline { 2 - 3 } & Fruit Mass $(\mathrm{kg})$ & Yield $\left(\mathrm{kg} \mathrm{ha}^{-1}\right)$ \\
\hline Control & 1.452 & 55865.38 \\
Additional & 1.458 & 56079.81 \\
\hline Linear contrast & & \\
Control vs Additional & $\mathrm{p}=0.8673$ & $\mathrm{p}=0.8658$ \\
$\mathrm{CV}(\%)$ & 3.064 & 3.071 \\
\hline
\end{tabular}

Note. Comparison between treatments with linear contrast.

In general, the several fertigation frequencies tested allowed high yields and adequate fruit quality in the cultivation of pineapple under the studied conditions. The results obtained in the present work are similar to those obtained by Veloso et al. (2001), studying the response of 'Pérola' pineapple crop to the application of nitrogen and potassium in Oxisols located in the northeastern region of Pará. They analized four doses of $\mathrm{N}$ and four doses of $\mathrm{K}$ divided into four applications. The authors, as well as in the present study, verified that the $\mathrm{N}$ fertilization frequencies had no effect on the productivity and fruit mass with crown.

The explanation for the non-occurrence of different yields is that during the experiment the plants did not go through periods of nutritional deficiency or water deficit.

The average yield value obtained in the experiment was $56253.72 \mathrm{~kg} \mathrm{ha}^{-1}$. The obtained value surpasses the $40,600 \mathrm{~kg} \mathrm{ha}^{-1}$ obtained by Rodrigues et al. (2013) with Pérola crop under rainfed conditions, in the city of Santa Rita, in the Tabuleiros Costeiros region on Paraíba State. It was also higher than the $42,000 \mathrm{~kg} \mathrm{ha}^{-1}$ estimated by Oliveira et al. (2014) for the BRS Imperial pineapple variety, close to $58,625 \mathrm{~kg} \mathrm{ha}^{-1}$ reached by Pinheiro Neto (2009) with fertigated pineapple 'MD-2' in Mossoró, Rio Grande do Norte State, and below the 77,200 kg ha-1 reported by Melo et al. (2006) in irrigated and non-fertigated Pérola crop in São Cristóvão, Sergipe.

In the treatment in which $\mathrm{K}$ fertigations were applied once a week $(\mathrm{K}=35)$, the average fruit mass with crown and productivity were lower in relation to the other fertigation frequencies (Table 1), while there was a trend for higher fruit mass and yield on monthly $\mathrm{K}$ applications $(\mathrm{K}=9)$ and on four applications throughout crop cycle $(\mathrm{K}$ $=4)$.

Teixeira et al. (2002), observed that fertilization with $\mathrm{N}$ and $\mathrm{K}$ in five applications promoted higher fruit mass and productivity. Furthermore, Veloso et al. (2001), evaluating different potassium doses on Pérola pineapple crop, verified that the addition of $\mathrm{K}$ provided an increase in production, with a maximum productivity of 79,000 $\mathrm{kg} \mathrm{ha}^{-1}$ with a dose of $22 \mathrm{~g}$ plant $^{-1}$ of $\mathrm{K}_{2} \mathrm{O}$.

There was no significant effect among the $\mathrm{N}$ fertigation frequencies on fruits soluble solids content, $\mathrm{pH}$, titratable acidity (TA) and SS/TA ratio at a 5\% significance level (Table 3). On the other hand, the treatments with subdivision of the $\mathrm{K}$ fertilizations had significant effects on fruit pulp $\mathrm{pH}$ (Table 3 ). 
Table 3. Soluble solids (SS), $\mathrm{pH}$, titratable acidity (TA) and SS/TA ratio of 'Pérola' pineapple fruits, due to nitrogen $(\mathrm{N})$ and potassium $(\mathrm{K})$ fertigation frequencies

\begin{tabular}{|c|c|c|c|c|}
\hline \multirow{3}{*}{ Treatment } & \multicolumn{4}{|c|}{ Variables } \\
\hline & SS & $\mathrm{pH}$ & TA & SS/TA \\
\hline & ${ }^{\circ}$ Brix & & $\%$ citric acid & ratio \\
\hline \multicolumn{5}{|c|}{ Nfertigation frequencies } \\
\hline 1. $\mathrm{N}=54$ & $14.16 \mathrm{a}$ & $4.23 \mathrm{a}$ & $0.38 \mathrm{a}$ & $36.22 \mathrm{a}$ \\
\hline 2. $\mathrm{N}=27$ & $14.06 \mathrm{a}$ & $4.23 \mathrm{a}$ & $0.39 \mathrm{a}$ & $37.77 \mathrm{a}$ \\
\hline 3. $\mathrm{N}=7$ & $14.50 \mathrm{a}$ & $4.22 \mathrm{a}$ & $0.41 \mathrm{a}$ & $36.56 \mathrm{a}$ \\
\hline 4. $\mathrm{N}=4$ & $14.13 \mathrm{a}$ & $4.23 \mathrm{a}$ & $0.40 \mathrm{a}$ & $35.24 \mathrm{a}$ \\
\hline Average & 14.23 & 4.22 & 0.40 & 36.17 \\
\hline CV $(\%)$ & 4.01 & 1.53 & 12.00 & 11.00 \\
\hline \multicolumn{5}{|c|}{ K fertigation frequencies } \\
\hline 1. $\mathrm{K}=70$ & $14.10 \mathrm{a}$ & $4.21 \mathrm{~b}$ & $0.40 \mathrm{a}$ & $35.56 \mathrm{a}$ \\
\hline 2. $K=35$ & $14.24 \mathrm{a}$ & $4.19 \mathrm{~b}$ & $0.41 \mathrm{a}$ & $35.36 \mathrm{a}$ \\
\hline 3. $K=9$ & $14.21 \mathrm{a}$ & $4.22 \mathrm{ab}$ & $0.40 \mathrm{a}$ & $36.56 \mathrm{a}$ \\
\hline 4. $K=4$ & $14.29 \mathrm{a}$ & $4.28 \mathrm{a}$ & $0.38 \mathrm{a}$ & $38.31 \mathrm{a}$ \\
\hline Average & 14.23 & 4.22 & 0.40 & 36.17 \\
\hline CV $(\%)$ & 4.01 & 1.53 & 12.00 & 11.00 \\
\hline
\end{tabular}

Note. Means followed by the same letter do not differ statistically from each other, at the $5 \%$ probability level, by the Tukey test.

$\mathrm{N}=54$ applications (twice a week fertigations); $\mathrm{N}=27$ applications (once a week fertigations); $\mathrm{N}=7$ applications (monthly fertigations); $\mathrm{N}=4$ applications (fertigation divided in four applications) throughout crop cycle. $\mathrm{K}=70$ applications (twice a week fertigations); $\mathrm{K}=35$ applications (once a week fertigations); $\mathrm{K}=9$ applications (monthly fertigations); $\mathrm{K}=4$ applications (fertigation divided in four applications) throughout crop cycle.

Table 4. Effect of irrigation on soluble solids (SS), $\mathrm{pH}$, titratable acidity (TA) and SS/TA ratio of pineapple 'Pérola' fruit conducted with different frequencies of nitrogen $(\mathrm{N})$ and potassium $(\mathrm{K})$ application by fertigation

\begin{tabular}{|c|c|c|c|c|}
\hline \multirow{3}{*}{ Treatment } & \multicolumn{4}{|c|}{ Variables } \\
\hline & $\mathrm{SS}$ & $\mathrm{pH}$ & $\mathrm{TA}$ & SS/TA \\
\hline & ${ }^{\circ}$ Brix & & $\%$ citric acid & ratio \\
\hline Control & 14.358 & 4.184 & 0.409 & 35.254 \\
\hline Additional & 14.383 & 4.017 & 0.444 & 32.592 \\
\hline \multicolumn{5}{|l|}{ Linear Contrast } \\
\hline Control $V_{S}$ Additional & $\mathrm{p}=0.9436$ & $\mathrm{p}=0.9493$ & $\mathrm{p}=0.2388$ & $\mathrm{p}=0.2980$ \\
\hline $\mathrm{CV}(\%)$ & 3.367 & 1.402 & 8.864 & 9.739 \\
\hline
\end{tabular}

Note. Comparison between treatments with linear contrasts.

Although the subdivision of $\mathrm{N}$ fertigations did not influence the quality characteristics of the 'Pérola' pineapple (Table 3), the fruit chemical characteristics obtained were consistent with the descriptions of the pineapple variety studied performed by Araujo et al. (2012), as: a) Soluble solids ( $\left.{ }^{\circ} \mathrm{Brix}\right)=16.1 \mathrm{vs} 14.23$ (present study); b) titratable acidity $(\%)=0.42 v s 0.40$ (present study); c) SS/AT ratio $=32.6$ vs 36.17 (present study).

In general, there was a tendency for a decrease in $\mathrm{pH}$ with the increase on $\mathrm{K}$ application frequencies. This tendency was also observed by Francisco (2014), who verified a decrease in $\mathrm{pH}$ values with higher subdivisions of K fertigations, performed with 20 days intervals. Ramos et al. (2010) reported a reduction in fruits $\mathrm{pH}$ on 'BRS Imperial' pineapple variety, and also K deficiency.

The decrease in $\mathrm{pH}$ can be attributed to the role of $\mathrm{K}$ in the neutralization of organic acids in the plants (Taiz \& Zeiger, 2013). Hence, $\mathrm{K}$ deficiency in fruits can cause a reduction in $\mathrm{pH}$. However, the low $\mathrm{pH}$ value usually presented in most fruit pulps has the advantage of being a limitation for the proliferation of pathogenic bacteria, contributing to keep contamination levels low (Santos et al., 2008). 
The averages obtained for soluble solids are within the values recommended by M. I. F. Chitarra and A. B. Chitarra (2005) that are between $13.2^{\circ} \mathrm{Brix}$ and $14.3^{\circ} \mathrm{Brix}$. As for the titratable acidity, the values are in agreement with those verified by Bengozi et al. (2007), which was $0.38 \%$ to $0.59 \%$.

The results of the titratable acidity analysis were expected to coincide with the $\mathrm{pH}$ results, since the decrease in $\mathrm{pH}$ is inversely proportional to the decrease in acidity. In this study, the decrease in $\mathrm{pH}$ did not imply an increase in the titratable acidity (Table 3). Besides fertigation management, the quality of the fruit is also related to climatic, cultural and genetic factors (M. I. F. Chitarra \& A. B. Chitarra, 2005). Therefore, depending on the crop management applied and the climatic conditions of each region, differences in fruit quality can be observed for the same variety.

The SS/TA ratio in all treatments resulted in values from 35.24 to 38.31 (Table 3). This ratio corresponds to the balance between sweetness and acidity. In the present work the titratable acidity was relatively low, which contributed to higher SS/AT values. According to M. I. F. Chitarra and A. B. Chitarra (2005), the SS/AT ratio is an index that reflects the palatability of the fruits and is widely used to assess and classify the flavor, being more expressive than the isolated measurement of sugars or acidity, as it reflects the balance between them.

The quality variables of the 'Pérola' pineapple fruits obtained in the present work are in the range considered adequate of organoleptic quality for in natura consumption. Soluble solids were above the minimum required value of $12^{\circ}$ Brix recommended for the harvesting and commercialization of pineapples in Brazil, according to the Pineapple Classification Standards (Ceagesp, 2003).

\section{Conclusion}

The results showed that the effect of $\mathrm{K}$ frequencies applied through fertigation on pineapple yield and fruit physical and chemical quality was more pronounced in comparison to the effect of subdivision of $\mathrm{N}$ fertigations. Overall, monthly $\mathrm{K}$ fertigations $(\mathrm{K}=9)$, followed by four applications throughout the crop cycle $(\mathrm{K}=4)$, provided the greatest increase in fruit quality, allowing higher values of fruit mass, yield and $\mathrm{pH}$.

\section{References}

Araujo, J. R. G., Aguiar, R. A. J., Chaves, A. M. F., Reis, F. O., \& Martins, M. R. (2012). Pineapple "Turiaçu”: traditional crop native from Maranhão. Brazilian Journal of Fruticulture, 34, 1270-1276.

Benfica, A. F., Oliveira, A. M. G., Cardoso, C. E. L., Junghans, D. T., Reinhardt, D. H., Cunha, G. A. P., ... Sanches, N. (2011). Pineapple production system for southern Bahia.

Bengozi, F. J., Sampaio, A. C., Gutierrez, A. D. de S., Rodrigues, V. M., \& Pallamin, M. L. (2007). Physical and chemical qualities of pineapple marketed at Ceagesp-São Paulo. Brazilian Journal of Fruticulture, 29, 540-545.

Borges, A. L., \& Silva, D. J. (2011). Irrigation and fertigation in fruit trees and vegetables. Brasília, Embrapa Technological Information. Retrieved from http:// http://livraria.sct.embrapa.br/liv_resumos/pdf/00061500. pdf

CEAGESP (Companhia de Entrepostos e Armazéns Gerais de São Paulo). (2003). Brazilian program for modernization of horticulture: Classification norms for pineapple. São Paulo: Quality Center in Horticulture. Retrieved from http://www.hortibrasil.org.br/images/stories/folders/abacaxi.pdf

Chitarra, M. I. F., \& Chitarra, A. B. (2005). Post-harvest and quality of fruits and vegetables: Physiology and handling. Lavras, MG: ESAL/FAEPE.

FAO (Food and Agriculture Organization of the United Nations). (2016). Retrieved from http://faostat.fao.org/ site/567/DesktopDefault.aspx? PageID $=567$

Francisco, J. P. (2014). Fertigation with vinasse on pineapple variety 'Vitória': Effects on soil and plant (Master Thesis, São Paulo University, São Paulo, Brazil).

IBGE (Brazilian Institute of Geography and Statistics). (2017). Systematic survey of agricultural production. LSPA.

Melo, A. S., Netto, A. O. A., Neto, J. D., Brito, M. E. B., Viégas, P. R. A., Magalhães, L. T. S., \& Fernandes, P. D. (2006). Vegetative development, fruit yield and optimization of pineapple variety 'Pérola' at different levels of irrigation. Rural Science Journal, 36, 93-98. https://doi.org/10.1590/S0103-84782006000100014

Mendes, R. M., Krause, W., Rocha, L. A., Souza, F. L., \& Souza, C. B. (2011). Nitrogen Sources and Potassium Chloride Doses in Pineapple crop (pp. 2178-74924). Conference of Scientific Initiation. Cáceres, Brazil: University of Mato Grosso. 
Oliveira, A. M. G. (2014). Levels of $N$-K fertilization on pineapple 'BRS Imperial' in the extreme south of Bahia (Doctoral Thesis, Faculty of Agricultural and Veterinary Sciences, Jaboticabal, Brazil).

Papadopoulos, I. (2001). Fertigation: Flowers, fruits and vegetables (2nd ed.). Guaíba, RS: Agropecuária.

Pinheiro Neto, L. G. (2009). Growth, production and quality of pineapple fertigated with different sources and doses of nitrogen and potassium. Rural University of Semi-Arid, Mossoró, Brazil.

Ramos, M. J. M., Monnerat, O. H., Pinho, L. G. R., \& Carvalho, A. J. C. (2010). Sensory quality of the fruits of Imperial pineapple cultivated under macronutrients and boron deficiency. Brazilian Journal of Fruticulture, 32, 692-699. http://doi.org/10.1590/S0100-29452010005000106

Rodrigues, A. A., Mendonça, R. M. N., Silva, A. P. da, \& Silva, S. de M. (2013). Mineral nutrition and 'Pérola' pineapple yield as a function of $\mathrm{K} / \mathrm{N}$ ratios in fertilization. Brazilian Journal of Fruticulture, 35, 625-633.

Santos, C. A. A., Coelho, A. F. F., \& Carreiro, S. C. (2008). Microbiological evaluation of frozen fruit pulps. Food Science and Technology, 28, 913-915. https://doi.org/10.1590/S0101-20612008000400023

Silva, E. R. da. (2014). Productivity, fruit quality and radicular development of drip irrigated pineapple (Doctoral Thesis, Paulista State University, Jaboticabal, Brazil).

Simão, A. H., Mantovani, E. C., \& Simão, F. R. (2004). Irrigation and fertigation in mango crop. In D. E. Rozane, R. J. Darezzo, R. L. Aguiar, G. H. A. Aguilera, \& L. Zambolim (Eds.), Mango-Integrated production, industrialization and commercialization (pp. 234-302). Viçosa, MG: Federal University of Viçosa.

Souza, L. F. da S. (1999). Pineapple, cultivation, agribusiness and economy. Brasília, DF: Embrapa, Communication for Technology Transfer.

Taiz, L., \& Zeiger, E. (2013). Plant Physiology (5th ed.). Porto Alegre, RS: ArtMed.

Teixeira, L. A. J., Spironello, A., Furlani, P. R., \& Sigrist, J. M. M. (2002). NPK fertilizer parceling in pineapple. Brazilian Journal of Fruticulture, 24, 219-224.

Veloso, C. A. C., Oeiras, A. H. L., Carvalho, E. J. M., \& Souza, F. R. (2001). Response of pineapple to the addition of nitrogen, potassium and limestone in Yellow Latosol on Northeast of Paraná state. Brazilian Journal of Fruticulture, 23, 396-402.

\section{Copyrights}

Copyright for this article is retained by the author(s), with first publication rights granted to the journal.

This is an open-access article distributed under the terms and conditions of the Creative Commons Attribution license (http://creativecommons.org/licenses/by/4.0/). 